\title{
Elderly caregivers living in urban, rural and high social vulnerability contexts
}

\author{
Idosos cuidadores que moram em contextos urbanos, rurais e de alta vulnerabilidade social \\ Ancianos cuidadores que viven en contextos urbanos, rurales y de alta vulnerabilidad social
}

Sofia Cristina lost Pavarini ${ }^{1}$, Anita Liberalesso Neri' ${ }^{2}$, Allan Gustavo Brigola ${ }^{3}$, Ana Carolina Ottaviani ${ }^{3}$, Érica Nestor Souza ${ }^{3}$, Estefani Serafim Rossetti ${ }^{3}$, Mariélli Terassi ${ }^{3}$, Nathalia Alves de Oliveira ${ }^{3}$, Bruna Moretti Luchesi ${ }^{3}$

How to cite this article:

Pavarini SCI, Neri AL, Brigola AG, Ottaviani AC, Souza EM, Rossetti ES, et al. Elderly caregivers living in urban, rural and high social vulnerability contexts Rev Esc Enferm USP. 2017;51:e03254. DOI: http://dx.doi.org/10.1590/S1980-220X2016040103254

${ }^{1}$ Universidade Federal de São Carlos, Departamento de Gerontologia, Programa de Pós-Graduação em Enfermagem/

Programa de Pós-Graduação em Gerontologia, São Carlos, SP, Brazil.

${ }^{2}$ Universidade Estadual de Campinas, Faculdade de Educação, Campinas, SP, Brazil.

${ }^{3}$ Universidade Federal de São Carlos, Programa de Pós-Graduação em

Enfermagem, São Carlos, SP, Brazil.

\begin{abstract}
Objective: Comparing the differences in the sociodemographic, care and health profiles of elderly caregivers of the elderly living in urban, rural, and high social vulnerability contexts. Method: A cross-sectional study developed with elderly caregivers enrolled in the Family Health Units of a municipality in the interior of São Paulo. Household interviews and evaluations were conducted on: Activities of Daily Living (ADL), selfreported pain, frailty, cognition, life satisfaction, family functionality, burden, stress and hope. Results: A total of 343 elderly caregivers of elderly individuals participated in the study, of which $55.1 \%$ lived in an urban context, $23.6 \%$ in rural areas, and $21.3 \%$ in a context of high social vulnerability. The majority of elderly caregivers were women across the three contexts, with a median age of 67 years and caring for their spouse. Caregivers from regions of high social vulnerability had lower education level, received less emotional and material help to care, were less satisfied with life, more fragile, in more cognitive decline, had worse family functionality and a lower level of hope when compared to caregivers of urban and rural contexts $(\mathrm{p} \leq 0.05)$. However, caregivers from areas of high vulnerability were more independent for ADL. Conclusion: Professionals working in Primary Care should consider these differences when planning interventions aimed at the specific group of caregivers.
\end{abstract}

\section{DESCRIPTORS}

Aged; Caregivers; Social Vulnerability; Rural Health; Urban Population; Geriatric Nursing.
Corresponding author:

Sofia Cristina lost Pavarini

Rodovia Washington Luís, Km 235, SP-310

CEP 13565-905 - São Carlos, SP, Brazil

sofiapavarini@gmail.com
Received: 10/11/2016

Approved: 04/25/2017 


\section{INTRODUCTION}

Changes in the demographic and epidemiological profile of the population have led to an increase in the number of elderly people with chronic diseases, which may compromise the functional capacity of the elderly and result in their needing of daily care ${ }^{(1)}$. Most care for the elderly emanates from informal and family networks. The literature points out some common characteristics of family caregivers such as being female, having a low level of education, or being the spouse or daughter of the elderly ${ }^{(2-3)}$.

Caring for an elderly person is a complex task that causes changes in the caregiver's life, and can be accentuated when the caregiver is also an elderly person, which is becoming a common fact due to population aging. In this sense, some studies have shown the growth in the number of people over 60 who play the role of informal caregivers of another more dependent elderly person ${ }^{(2,4-5)}$.

Care offered at home allows the elderly to be near their family; however, most families have low financial and social conditions, which can make caring a difficult task ${ }^{(6)}$. Regarding social vulnerability, the elderly have more impairments in their quality of life, increased physical and emotional burden, and may present more fragile health ${ }^{(7-8)}$.

In contexts distant from urban centers such as rural areas, care for dependent persons can also be influenced. In 2013, data from the Brazilian Institute of Geography and Statistics (IBGE - Instituto Brasileiro de Geografia e Estatística) show that close to $16 \%$ of the elderly lived in rural regions and communities ${ }^{(9)}$. The support network in the rural context is still fragile, and informal care networks prevail ${ }^{(10)}$.

Literature shows peculiarities regarding residing in urban, rural and high vulnerability contexts ${ }^{(6,8,10)}$. However, studies comparing the differences of these three contexts in older adults who play the role of caregivers to other elderly people are still scarce. This type of information may allow for creating programs and activities to support elderly caregivers focused on the characteristics of the context in which they are inserted, so that the programs are more effective and efficient in Primary Health Care. The data can therefore support interventions, guidelines and support for caregivers focused on health promotion, social interaction, improving quality of life, and preventing stressors and adversities which arise as a result of the care.

Considering the studied theme, this research aimed to compare the differences in the sociodemographic, care and health profiles of elderly caregivers of elderly persons who live in urban contexts, in rural contexts, and in contexts of high social vulnerability.

\section{METHOD}

This is a cross-sectional study developed with elderly caregivers from all Family Health Units (FHU) of a municipality in the interior of São Paulo. In the year 2014, the municipality had 17 Family Health Teams, of which 15 were in the urban area. The other two are located in two districts of the municipality that are distant from the urban center, attending to the farms in the region. The area covered by these two
FHU was considered as the rural area for this study. On the other hand, the teams from the urban area were divided according to the social vulnerability assessed by the Index of Social Vulnerability of the state of São Paulo (IPVS - Indice Paulista de Vulnerabilidade Social) which considers socioeconomic variables (income per capita, literacy) and demographic variables (age, gender). Five were located in areas of high social vulnerability (IPVS=5), and ten among average and low vulnerability areas (IPVS $=2$ to 4 ). FHUs located in areas with IPVS $=5$ were considered as areas of high vulnerability, and those located in areas with IPVS $=2$ to 4 as urban areas.

The study population were elderly (60 years of age or older) enrolled in the FHU of the municipality. Inclusion criteria were: being a primary caregiver of a dependent elderly ( $\geq 60$ years old) living in the same household. To be considered dependent, the elderly had to be dependent for at least one Basic Activity of Daily Life (BADL), as evaluated by the Katz Index ${ }^{(11)}$, and/or Instrumental Activity of Daily Living (IADL) as evaluated by the Lawton and Brody Scale ${ }^{(12)}$. These instruments were also applied to the elderly caregiver, who should be more independent than the elderly dependent that they lived with.

The sample was selected from a total of 594 residences listed by the Family Health teams where two or more elderly people lived, and resulted in 351 interviewed elderly caregivers of the elderly. Of the 351 participants who completed the questionnaire, eight were excluded from the present analysis for not completing the health assessment. The final sample consisted of 343 elderly caregivers, divided into three groups according to their place of residence: urban area $(n=189)$, high social vulnerability area $(n=73)$ or rural area $(n=81)$.

The interviews took place in the homes of the elderly from April to November 2014, and were carried out by postgraduates of the nursing and gerontology areas, duly trained to carry out the evaluations.

The evaluation included three aspects: 1 Sociodemographic characterization: gender, age and schooling; 2) Characterization of the care context: degree of relationship to the care-dependent elderly (spouse, child, daughter/sonin-law, brother/sister, other), monthly family income (in Brazilian currency reais), number of people living in the household, whether there were any children in the house (yes/no), whether material help was provided to care for the elderly (yes/no), and whether emotional help was provided to care for the elderly (yes/no); 3) Characterization of the health conditions, evaluating: BADL: Katz index ${ }^{(11)}$, elderly caregivers were considered as dependent if they were dependent for at least one of the six BADLs, and as independent for the others; IADL: Lawton and Brody Scale ${ }^{(12)}$, elderly caregivers with scores equal to 21 points were considered independent, and those with scores between 8 and 20 as partially dependents; Self-reported pain: feels pain (yes/no); Frailty: evaluated according to the five-component phenotype ${ }^{(13)}$; Unintentional weight loss (indicated by the affirmative answer of loss greater than $4.5 \mathrm{~kg}$ or $5 \%$ of body weight to the question "In the past 12 months do you think you have lost weight without dieting?"; Fatigue (assessed by responses "always" or "most of the time" on any of the two issues of 
the Center for Epidemiological Studies - Depression, CES-D: 1). In the past week, how often did you feel that everything you did required a lot of effort? and 2) How often in the past week did you feel that you would not be able to carry out your activities?); Low hand grip strength (indicated by the mean of three consecutive grip strength measurements of the dominant hand, in Kgf, using a Jamar SH5001 hydraulic dynamometer, manufactured by SAEHAN ${ }^{\circledR}$, Lafayette, Illinois, USA), elderly with the lowest gender-adjusted quintile of strength and Body Mass Index (BMI) scored for the component; Slow gait (indicated by the average of three consecutive measures of the time in seconds that the elderly spent to walk $4.6 \mathrm{~m}$ in a straight line on a flat surface at their usual gait, being allowed to use a walking stick or walker; to provide acceleration and deceleration of gait two meters before and two meters after were included in the course, thus totaling $8.6 \mathrm{~m}$ of walking): those $20 \%$ slower according to gender and mean height scored for the component; and Low level of physical activity (indicated by affirmative answer to item "Do you think you do less physical activity than 12 months ago?"): the presence of three or more components of the phenotype characterize the person as frail, of one or two criteria as pre-frail, and none of the criteria as non-frail. For the analyzes, the frail elderly group was compared to the non-frail/pre-frail elderly group; Cognition: Addenbrooke's Cognitive Examination Revised (ACE-R) ${ }^{(14)}$, which includes five domains (orientation/attention, memory, verbal fluency, language and visual-constructive ability) and the overall score ranges from 0 to 100 points, where the higher the score, the better the cognitive performance. A cut-off score of 65 points was used, which obtained a sensitivity of $75.6 \%$ and a specificity of $73.8 \%$ in a sample of Brazilian elderly in a community with different levels of education $^{(15)}$. The groups above and below the cut-off value were compared; Satisfaction with life: the elderly were asked "Are you satisfied with your life?" (a little/more or less/very). For the analysis, the elderly respondents who were very satisfied with their life were considered; Family Functionality: Family APGAR, which had its psychometric properties tested in the elderly ${ }^{(16)}$, measuring satisfaction regarding five components of adaptability, partnership, growth, affection and problem-solving capacity. The scoring results in a score between 1 to 20, with scores over 13 representing good family functionality. For the analysis, we considered the elderly who had good family functionality; Care-Related Burden: Zarit Burden Inventory $(\mathrm{ZBI})^{(17)}$, which contains 22 items that assess the perceived impact of caregiving on the physical and emotional health, social activities, and financial condition of the caregiver. The total score is obtained by summing all items and can vary from 0 to 88 , where the higher the score, the greater the intensity of burden experienced by the caregiver. Elderly caregivers were divided into groups above and below the median of the sample (median=15); Stress: Perceived Stress Scale (PSS) ${ }^{(18)}$, which has 14 items that indicate the level of stress perceived by the elderly. The final score is the sum of the responses and ranges from 0 to 56 , where the higher the score, the higher the level of perceived stress. The elderly caregivers were divided into groups, above and below the median of the sample (median=17); and Hope: Herth Hope Scale (HHS) ${ }^{(19)}$, which has 12 items to evaluate the level of hope. The total score varies from 12 to 48 , and the higher the score, the higher the level of hope. Elderly caregivers were divided into groups above and below the median of the sample for the analyses (median=42).

Data were analyzed in SPSS software. Simple and median frequency calculations were performed for the variables in each of the three groups: urban, rural and high vulnerability. The results present three types of comparison: urban versus rural, urban versus high vulnerability, and rural versus high vulnerability. The groups were compared using chi-square tests for categorical variables and Mann-Whitney $U$ for continuous variables. A level of significance $\mathrm{p} \leq 0.05$ was considered.

The research project was approved by the Human Research Ethics Committee of the Universidade Federal de São Carlos (opinion number 416.467/2013). All participants signed the Informed Consent Form before the interview.

\section{RESULTS}

Of the 343 elderly caregivers evaluated, 189 (55.1\%) lived in the urban area, $81(23.6 \%)$ in the rural area, and 73 $(21.3 \%)$ in the high social vulnerability area.

Table 1 shows the frequency, median and $\mathrm{p}$-value data for the comparisons between the groups regarding the sociodemographic, care and health profiles.

Table 1 - Comparison of elderly caregivers residing in urban, rural and high vulnerability contexts regarding the sociodemographic, care and health profiles - São Carlos, São Paulo, Brazil, 2014.

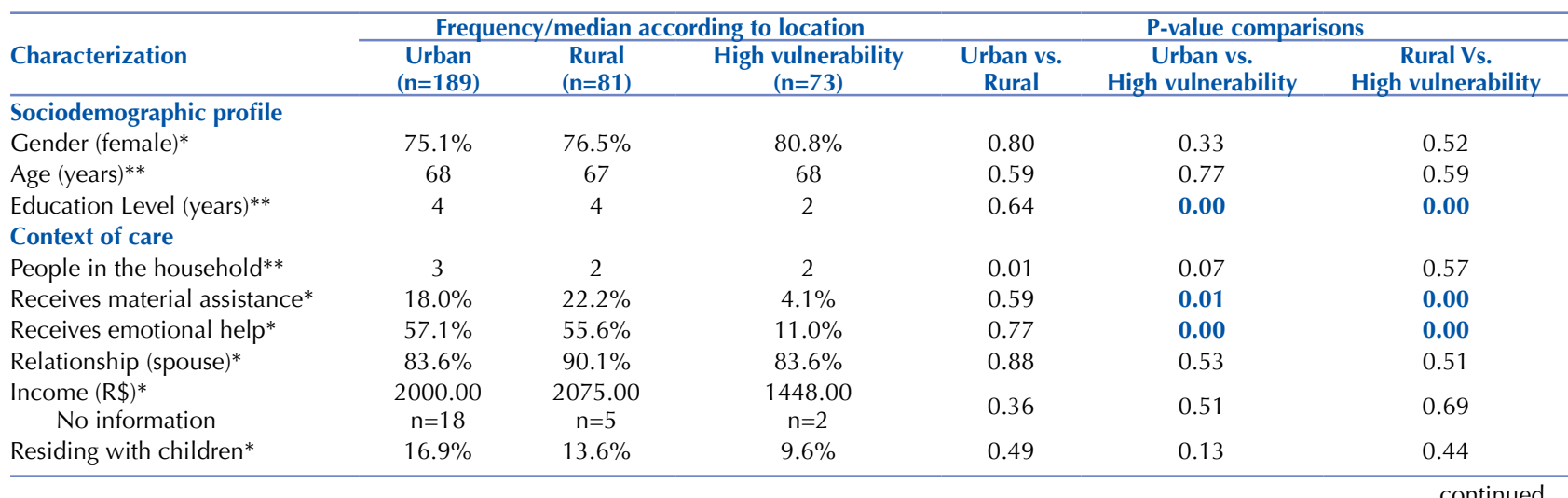




\begin{tabular}{|c|c|c|c|c|c|c|}
\hline \multirow[b]{2}{*}{ Characterization } & \multicolumn{3}{|c|}{ Frequency/median according to location } & \multicolumn{3}{|c|}{ P-value comparisons } \\
\hline & $\begin{array}{l}\text { Urban } \\
(n=189)\end{array}$ & $\begin{array}{c}\text { Rural } \\
(n=81)\end{array}$ & $\begin{array}{c}\text { High vulnerability } \\
(n=73)\end{array}$ & $\begin{array}{c}\text { Urban vs. } \\
\text { Rural }\end{array}$ & $\begin{array}{c}\text { Urban vs. } \\
\text { High vulnerability }\end{array}$ & $\begin{array}{c}\text { Rural Vs. } \\
\text { High vulnerability }\end{array}$ \\
\hline \multicolumn{7}{|l|}{ Health } \\
\hline Katz (independent)* & $85.2 \%$ & $84.0 \%$ & $94.5 \%$ & 0.79 & 0.04 & 0.04 \\
\hline Lawton (independent)* & $36.5 \%$ & $49.4 \%$ & $49.3 \%$ & 0.04 & 0.05 & 0.90 \\
\hline Feels pain* & $63.5 \%$ & $60.5 \%$ & $57.5 \%$ & 0.64 & 0.37 & 0.71 \\
\hline Frailty (frail)* & $19.6 \%$ & $9.9 \%$ & $37.0 \%$ & 0.05 & 0.00 & 0.00 \\
\hline ACE-R (above the cut-off point)* & $54.5 \%$ & $58.0 \%$ & $19.2 \%$ & 0.59 & 0.00 & 0.00 \\
\hline $\begin{array}{l}\text { Satisfaction with life } \\
\text { (very satisfied)* }\end{array}$ & $82.5 \%$ & $80.2 \%$ & $60.3 \%$ & 0.65 & 0.00 & 0.01 \\
\hline APGAR (good functionality)* & $88.9 \%$ & $86.4 \%$ & $74.0 \%$ & 0.56 & 0.00 & 0.05 \\
\hline ZBI (above the median)* & $53.4 \%$ & $53.1 \%$ & $41.1 \%$ & 0.95 & 0.07 & 0.14 \\
\hline PSS (above the median)* & $52.9 \%$ & $42.0 \%$ & $64.4 \%$ & 0.10 & 0.09 & 0.00 \\
\hline HHS (above the median)* & $57.1 \%$ & $71.6 \%$ & $34.2 \%$ & 0.02 & 0.00 & 0.00 \\
\hline
\end{tabular}

${ }^{*}$ Chi-square test. ${ }^{* *}$ Mann-Whitney U test. ACE-R=Addenbrooke's Cognitive Examination Revised. ZBI=Zarit Burden Inventory. PSS=Perceived Stress Scale. HHS=Herth Hope Scale. Medians established: $Z B B=15 ; \mathrm{PSS}=17 ; \mathrm{HHS}=42$. Note: $(\mathrm{n}=343)$.

The sociodemographic profile of the elderly caregivers of the three groups showed that they were mostly female with a median age of 67 years, and with low educational level. In all contexts the majority took care of their spouse, lived in homes without children and with two or three people in the household.

Elderly caregivers living in rural areas generally had better performance in health conditions. They were the caregivers with the lowest percentage of frailty (9.9\%), with better cognitive performance (58\% above the median in the ACE$\mathrm{R})$, less stressed (64.4\% above the median in the PSS), less burdened ( $42 \%$ above the median in the ZBI) and with a higher level of hope (71.6\% above the median in the HHS).

Comparing the group of elderly caregivers from the urban area and those from the rural area, the first group showed a larger number of people living in the household and a higher percentage of frail caregivers. On the other hand, caregivers living in rural areas were more independent for IADL and had a higher level of hope.

The results showed that the greatest differences were found in the comparison between urban contexts and high social vulnerability groups. For these groups, differences were found in the variables: education level, material help, emotional help, Katz and Lawton, frailty, ACE-R, life satisfaction, APGAR and HHS. The group of elderly caregivers who lived in urban areas presented higher education, received more material and emotional help, had fewer frail caregivers, had better cognitive performance, were more satisfied with life, had better family functionality and a higher level of hope than the elderly caregivers from areas of high social vulnerability. In contrast, the group living in areas of high vulnerability was more independent for both BADL and IADL.

In the comparison between groups in the rural area and in areas of high vulnerability, we found that the group residing in more vulnerable areas had lower education, received less material and emotional help for the care, was more frail, had worse cognitive performance, were less satisfied with life, had worse family functionality, had a higher level of perceived stress, and a lower level of hope. The only variable that was better for this group compared to the rural area group was performance in BADL.

\section{DISCUSSION}

Regarding the sociodemographic characteristics of the elderly caregivers, no differences were found regarding gender, age or family income in the different contexts. The data corroborate the literature regarding a predominance of women close to 70 years of age caring for elderly persons $^{(3-4)}$. Although no significant differences were found in the comparison of monthly family income, elderly caregivers from areas with high social vulnerability had lower median income. Moreover, it is pointed out that this variable was not reported by a total of 25 elderly people, which may have interfered in the comparison results.

As for educational level, elderly caregivers in contexts of high social vulnerability presented lower median than those from other contexts. A lower level of education in individuals living in these regions may demonstrate more fragile health ${ }^{(7)}$.

Evaluating the characteristics of care, caregivers living in areas of high social vulnerability received less material and emotional help, which corroborates findings in a study carried out in the Municipality of Natal (Rio Grande do Norte state) with 300 elderly people, where the elderly presented a weak support network, often only offered by some neighbors ${ }^{(20)}$. Another study identified that elderly people living in regions of high vulnerability have a large social network; however, only a few members play a functional role, that is, providing or receiving support ${ }^{(21)}$.

The results showed that the elderly caregivers who lived in the rural area had better performance in the variables related to the health evaluation. In contrast, elderly caregivers residing in areas of high social vulnerability had better performance for ADL and worse performance in all other health variables except pain and burden, which did not present significant differences in the comparison.

A study of elderly people with diabetes mellitus living in rural and urban areas found that those living in rural areas had a higher quality of life score in the domains: physical and social relationships; and in the aspects of autonomy, past, present and future activities, and intimacy; in addition, they presented better health conditions when compared to those living in the urban area ${ }^{(22)}$. Our findings showed that 
rural caregivers were comparatively more satisfied with life and had a better evaluation of health conditions than those living in regions of high social vulnerability.

Rural elderly caregivers were also more independent for instrumental activities of daily living compared to urban ones, which corroborates a study carried out with rural elderly in Uberaba, Minas Gerais state ${ }^{(23)}$.

The use of health care services in different contexts may also explain the results found. A study carried out with a sample of 100 informal caregivers of elderly people in palliative care found that the use of the family physician, emergency services, pharmacy, and services for caregiver relief were higher among rural caregivers ${ }^{(24)}$.

The frailty variable was different for the comparison between all contexts evaluated. In the rural area, the percentage of frail elderly caregivers was the lowest (9.9\%), followed by the urban area (19.6\%) and areas of high vulnerability (37.0\%). A systematic review of the literature examined the factors associated with frailty in 35 studies, and found an association with education level and cognitive function, among other aspects ${ }^{(25)}$. The elderly caregivers of the present study who lived in contexts of high vulnerability were those that presented the lowest schooling and worse cognitive performance, which may be related to the percentage of frail elderly. In contrast, the review study also found that functional disability is associated with frailty in the elderly ${ }^{(25)}$, which contradicts the data of the current study, since caregivers from the most vulnerable region were more independent for BADL and IADL. This is an interesting fact, since it can be noticed that despite presenting worse performance in several variables of health evaluation, elderly caregivers in high vulnerability contexts are more independent. Attempts to explain this data are based on the fact that these elderly have worse family functionality and receive less material and emotional help, therefore they cannot count on the support of other people to assist in ADLs, which causes them to continue to perform the activities alone, despite their poor cognitive performance and frailty. Nonetheless, future research should seek to better understand the relationship between functional disability, frailty and cognitive performance in elderly caregivers residing in regions with high social vulnerability.

It is important to highlight that the percentage of elderly frail caregivers was high in all regions, which raises reflections on the performance of the caregiver role by an elderly person who is also frail.

The results found in the present study showed worse cognitive performance in the elderly in a context of high social vulnerabilitywhen compared to the urbanand rural areas. These data corroborate a multicentric study conducted in Brazilwith 878 elderlypeople, which identified that cognitiveimpairment is associated with poverty ${ }^{(26)}$. Cognitive impairment may be associated with less access to stimuli and less development of a sense of self-efficacy. Social interaction and leisure activities are factors that can contribute to this commitment, since they help maintain autonomy and favor physical and psychological well-being $^{(21-22)}$, and they can be adversely affected as a result of social vulnerability and poverty contexts.
In the present study, the family functionality of urban and rural caregivers did not differ. For those residing in a high vulnerability area, a lower percentage of elderly with good family functionality was observed. A recent study found that family relationships influence the well-being of older people living in rural communities in Thailand ${ }^{(27)}$. Another study comparing family functionality of caregivers of the elderly found no significant differences for those living in regions of high and very high social vulnerability, and those living in regions of low and medium social vulnerability ${ }^{(28)}$. The data presented differ from the current results; however, the caregivers in the study sample cited had a mean age of 50 years and only $76.4 \%$ lived with the elderly they were caregiver to. The remainder cared for the elderly, but had another family, which may explain the differences found.

Only $34.2 \%$ of elderly caregivers from high vulnerability areas scored above the median on the HHS, meaning that they had higher levels of hope. An investigation with patients undergoing chemotherapy treatment found that the level of hope is positively associated with education levels ${ }^{(29)}$.

The differences in the sociodemographic, health and care profiles observed in this research bring relevant information for the future planning of interventions with caregivers who are elderly and live in different contexts.

The result of a systematic literature review that analyzed ten articles on interventions for family caregivers of frail elderly residents in a community found that most interventions focus on reducing stress levels and the burden of care, increasing knowledge about the disease of the dependent elderly and developing social skills. However, the researchers describe that the results of the interventions still show differences as to the effectiveness on the caregiver's quality of life and are inconsistent in the literature. This also draws attention to the need for interventions that fit different contexts in which caregivers are inserted ${ }^{(30)}$.

Regarding the high vulnerability context, the lack of individual, family and social resources to meet elderly and caregivers needs can cause harm to their quality of life and well-being. Family support for the care may be very important for the longevity of the elderly; in that sense, families in a context of poverty and who do not have sufficient financial resources to meet basic needs nor can they afford to hire third-party services to assist in the care may experience greater difficulties to support the family caregiver and the elderly receiving care $^{(8)}$.

Some limitations of this study can be pointed out. This is a cross-sectional study, conducted with a specific sample of elderly caregivers, and therefore the data cannot be generalized. It is also not possible to establish a cause and effect relationship. Further research in this area including studies with different designs are certainly necessary in the scope of Primary Health Care, especially considering the increasing number of informal caregivers with old age.

Despite its limitations, there is important information about positive aspects of care in these different contexts; among which the percentage of independent caregivers for 
ADL in contexts of high social vulnerability may be highlighted, and in the rural context, the low percentage of frail elderly people and high levels of hope.

\section{CONCLUSION}

The results showed that there are differences between elderly caregivers living in urban, rural and high social vulnerability contexts.

Elderly caregivers from a high social vulnerability context presented lower education and worse health and care conditions, with the exception of ADLs. Those in the rural context were the ones with the best performance in the evaluations, especially for frailty and hope.
Analyzing these differences considering the positive and negative aspects of each of these contexts, as well as possible protective and risk factors can certainly contribute to implementing interventions that also take care of these elderly caregivers. Primary Care services are the first level of health care, as well as the multiprofessional teams that work in these places, and have the responsibility of acting in health promotion and disease prevention. Furthermore, the group of caregivers of dependent people is still little attended by these interventions. Caring for the caregiver is an extremely important practice that can prevent future problems and improve the quality of life of these caregivers, and especially for those who are also elderly.

\section{RESUMO}

Objetivo: Comparar as diferenças no perfil sociodemográfico, de cuidado e de saúde de idosos cuidadores de idosos que vivem em contextos urbanos, rurais, e de alta vulnerabilidade social. Método: Estudo transversal desenvolvido com idosos cuidadores, cadastrados nas Unidades de Saúde da Família de um município do interior paulista. Foram realizadas entrevistas domiciliares e as avaliações: Atividades de Vida Diária (AVDs), dor autorrelatada, fragilidade, cognição, satisfação com a vida, funcionalidade familiar, sobrecarga, estresse e esperança. Resultados: Participaram do estudo 343 idosos cuidadores de idosos, dos quais 55,1\% viviam em contexto urbano, 23,6\% em rural, e 21,3\% em contexto de alta vulnerabilidade social. Nos três contextos, a maioria dos idosos cuidadores era mulher, com idade mediana de 67 anos e cuidava do cônjuge. Os cuidadores de regiões de alta vulnerabilidade social tinham pior escolaridade, recebiam menos ajuda emocional e material para cuidar, eram menos satisfeitos com a vida, mais frágeis, com mais declínio cognitivo, pior funcionalidade familiar e menor nível de esperança quando comparados aos cuidadores de contextos urbanos e rurais $(\mathrm{p} \leq 0,05)$. Porém, os cuidadores das áreas de alta vulnerabilidade eram mais independentes para as AVDs. Conclusão: Profissionais atuantes na Atenção Primária devem considerar essas diferenças quando forem planejar intervenções voltadas ao grupo específico de cuidadores.

\section{DESCRITORES}

Idoso; Cuidadores; Vulnerabilidade Social; Saúde da População Rural; População Urbana; Enfermagem Geriátrica.

\section{RESUMEN}

Objetivo: Comparar las diferencias en el perfil sociodemográfico, de cuidado y de salud de ancianos cuidadores de ancianos que viven en contextos urbanos, rurales, y de alta vulnerabilidad social. Método: Estudio transversal desarrollado con ancianos cuidadores, registrados en las Unidades de Salud de la Familia de un municipio del interior paulista. Se realizaron entrevistas domiciliarias y las evaluaciones: Actividades de Vida Diaria (AVDs), dolor autorrelatado, fragilidad, cognición, satisfacción con la vida, funcionalidad familiar, sobrecarga, estrés y esperanza. Resultados: Participaron del estudio 343 ancianos cuidadores de ancianos, de los cuales 55,1\% vivían en contexto urbano, el 23,6\% en rural, y el 21,3\% en contexto de alta vulnerabilidad social. En los tres contextos, la mayoría de los ancianos cuidadores era mujer, con edad mediana de 67 años y cuidaba al cónyuge. Los cuidadores de regiones de alta vulnerabilidad social tenían peor escolaridad, recibían menos ayuda emocional y material para cuidar, estaban menos satisfechos con la vida, más frágiles, con más declinación cognitiva, peor funcionalidad familiar y menor nivel de esperanza cuando comparados a los cuidadores de contextos urbanos y rurales $(\mathrm{p} \leq 0,05)$. Sin embargo, los cuidadores de las áreas de alta vulnerabilidad eran más independientes para las AVDs. Conclusión: Los profesionales que actúan en la Atención Primaria deben considerar estas diferencias cuando se planifican intervenciones dirigidas al grupo específico de cuidadores.

\section{DESCRIPTORES}

Anciano; Cuidadores; Vulnerabilidad Social; Salud Rural; Población Urbana; Enfermería Geriátrica.

\section{REFERENCES}

1. Oliveira AMS, Pedreira LC. Cuidadores de idosos dependentes no domicílio: mudanças nas relações familiares. Rev Bras Enferm. 2012;65(5):730-6.

2. National Alliance for Caregiving. Caregivers of older adults: focused look at those caring for someone age 50+ [Internet]. Bethesda: NAC; 2015 [cited 2015 July 30]. Available from http://www.caregiving.org/wp-content/uploads/2015/05/2015_CaregivingintheUS_CareRecipients-Over-50_WEB.pdf

3. Pinquart M, Sorensen S. Spouses, adult children, and children-in-law as caregivers of older adults: a meta-analytic comparison. Psychol Aging. 2011;26(1):1-14.

4. Tomomitsu MRSV, Perracini MR, Neri AN. Fatores associados à satisfação com a vida em idosos cuidadores de não cuidadores. Ciênc Saúde Coletiva. 2014; 19(8):3429-40.

5. Luchesi BM, Souza EN, Gratão ACM, Gomes GAO, Inouye K, Alexandre T, et al. The evaluation of perceived stress and associated factors in elderly caregivers. Arch Gerontol Geriatr. 2016;67:7-13.

6. Vieira CPB, Fialho AVM, Freitas CHA, Jorge MSB. Práticas do cuidador informal do idoso no domicílio. Rev Bras Enferm. 2011;64(3):570-9. 
7. Morley JE, Vellas B, Van Kan GA, Anker SD, Bauer JM, Bernabei R, et al. Frailty consensus: a call to action. J Am Med Dir Assoc. 2013;14(6):392-7.

8. Santos AA, Pavarini SCI. Perfil dos cuidadores de idosos com alterações cognitivas em diferentes contextos de vulnerabilidade social. Rev Gaúcha Enferm. 2010;31(1):115-22.

9. Instituto Brasileiro de Geografia e Estatística. Pesquisa Nacional por Amostra de Domicílios. Síntese de Indicadores 2013 [Internet]. Rio de Janeiro: IBGE; 2013 [citado 2015 nov. 20]. Disponível em: http://www.ibge.gov.br/home/estatistica/populacao/trabalhoerendimento/ pnad2013/default_sintese.shtm

10. Keating N, Fletcher S. Older rural and their families. In: Blieszner R, Bedford VH. Handbook of families and aging. Santa Barbara, California: Praeger; 2012. p. 309-35.

11. Katz S, Ford AB, Moskowitz RW, Jackson BA, Jaffe MW. The Index of ADL: a standardized measure of biological and psychosocial function. JAMA. 1963;185(12):94-9.

12. Lawton MP, Brody EM. Assessment of folder people: self-maintaining and instrumental activities of daily living. Gerontologist. $1969 ; 9(3): 179-86$.

13. Fried LP, Tangen CM, Waltson J, Newman AB, Hirshc C, Gottdiener J, et al. Frailty in older adults: evidence for a phenotype. J Gerontol A Biol Sci Med Sci. 2001;56(3):M146-56.

14. Carvalho VA, Caramelli P. Brazilian adaptation of the Addenbrooke's Cognitive Examination-Revised (ACE-R). Dement Neuropsychol. 2007;1(2):212-6.

15. César KG. Estudo da prevalência de comprometimento cognitivo leve e demência na cidade de Tremembé, estado de São Paulo [tese doutorado]. São Paulo, Universidade de São Paulo, Faculdade de Medicina; 2014.

16. Silva MJ, Victor JF, Mota FRN, Soares ES, Leite BMB, Oliveira ET. Análise da propriedade psicométricas do APGAR de família com idosos do nordeste brasileiro. Esc Anna Nery. 2014;18(3):527-32.

17. Scazufca M. Brazilian version of the Burden Interview scale for the assessment of burden of care in carers of people with mental illnesses. Rev Bras Psiquiatr. 2002;24(1):127.

18. Luft CB, Sanches SO, Mazo GZ, Andrade A. Versão brasileira da Escala de Estresse Percebido: tradução e validação para idosos. Rev Saúde Publica. 2007;41(4):606-15.

19. Sartore AC, Grossi SAA. Escala de Esperança de Herth: instrumento adaptado e validado para a língua portuguesa. Rev Esc Enferm USP. 2008;42(2):227-32.

20. Amaral FLJS, Guerra RO, Nascimento AFF, Maciel ACC. Apoio social e síndrome da fragilidade em idosos residentes na comunidade. Ciênc Saúde Coletiva. 2013;18(6):1835-46.

21. Brito TRP, Costa RS, Pavarini SCI. The elderly with cognitive alterations in the context of poverty: a study of the social support network. Rev Esc Enferm USP [Internet]. 2012 [cited 2015 Nov 20];46(4):906-13. Available from: http://www.scielo.br/pdf/reeusp/v46n4/en_18.pdf

22. Santos EA, Tavares DMS, Rodrigues LR, Dias FA, Ferreira PCS. Morbidity and quality of life of elderly individuals with diabetes mellitus living in urban and rural areas. Rev Esc Enferm USP. 2013;47(2):393-400.

23. Tavares DMS, Gavea Junior AS, Dias FA, Santos NMF, Oliveira PB. Qualidade de vida e capacidade funcional de idosos residentes na zona rural. Rev Rene. 2011;12(1):895-903.

24. Brazil K, Kaasalainen S, Willians A, Rodriguez C. Comparing the experiences of rural and urban family caregivers of the terminally ill. Rural Remote Health. 2013;13(1):2250.

25. Mello AC, Engstrom EM, Alves LC. Health-related and socio-demographic factors associated with frailty in the elderly: a systematic literature review. Cad Saúde Pública. 2014;30(6):1143-68.

26. Santos AA, Mansano-Scholosser TCS, Ceolim, MF, Pavarini SCI. Sono, fragilidade e cognição: estudo multicêntrico com idosos brasileiros. Rev Bras Enferm. 2013;66(3):351-7.

27. Rojpaisarnkit K. Factors influencing well-being in the elderly living in the rural areas of Eastern Thailand. Int J Behav Sci. 2016;12(2):31-50.

28. Santos AA, Pavarini SCI. Family functionality regarding the elderly with cognitive impairments: the caretaker's perception. Rev Esc Enferm USP [Internet]. 2012 [cited 2015 Nov 20];46(5):1141-7. Available from: http://www.scielo.br/pdf/reeusp/v46n5/en_15.pdf

29. Schuster JT, Feldens VP, Iser BPM, Ghislandi GM. Esperança e depressão em pacientes oncológicos em um hospital do Sul do Brasil. Rev AMRIGS. 2015;59(2):84-9.

30. Lopez-Hartmann M, Wens J, Verhoeven V, Remmen R. The effect of caregiver support interventions for informal caregivers of communitydwelling frail elderly: a systematic review. Int J Integr Care. 2012;12:e133. 